\title{
Asceticism, Gallantry, or Polygamy? Alexander's Relationsfip with Women as a Topos in Medieval Romance Traditions
}

\author{
Sabine Müller*
}

The legend of the ancient Macedonian ruler Alexander the Great was infused with new life in the Middle Ages. Medieval literature cast him as a popular subject, a moral exemplum and a model to be emulated by the nobility. One important aspect of this legend was his relationship with women that can be read as a marker of the different representations of the Alexander figure and their cultural contexts. This study examines the Alexander legend as it was reinvented in three major medieval texts, written by the French cleric Gautier de Châtillon, the German writer Johann Hartlieb and the Persian poet Nizami. While Christian literary representations reinvent Alexander as an ascetic, chaste figure, exalting fidelity to one woman, his wife Roxane and alternatively as an ideal of gallantry and courtliness, the Persian romance tradition portrayed him as an energetic, polygamous lover. In each case, his attitude towards women is deployed as a symbol of his political attributes.

The Macedonian ruler, conqueror of the Persian Empire and founder of a new short-lived empire, Alexander III (356-323 в.C.) became a legend soon after his death. Having been highly unpopular with the Macedonians during his lifetime, especially in the last years of his reign, he grew to be

Acknowledgements: I would like to thank Monica Juneja for her kind support and Richard Stoneman for a helpful discussion of the subject.

*Historisches Seminar, Leibniz University, Hannover. E-mail: sabine.mueller@ hist.unihannover.de

The Medieval History Journal, 11, 2 (2008): 259-287

SAGE Publications • Los Angeles/London/New Delfi/Singapore DOI: $10.1177 / 097194580801100204$ 
the most famous Macedonian ruler after his death. He was imitated by his successors who invoked his memory in order to seek legitimacy by declaring themselves his heirs. Alexander's image was consequently manipulated to serve their political aims. While the historical persona of Alexander faded away in Antiquity, the Alexander legend lived on throughout the Middle Ages and in early modern times. The ruler of Macedonia became a model emulated by aristocrats, courtiers, princes and kings. ${ }^{1}$ Irrespective of issues of historicity or fiction, the most popular episodes of the myth surrounding him came to be perceived as symbols of one or more heroic virtues such as courage, clemency, generosity, magnanimity, chastity and courtesy.

In a Christian view of the world, Alexander was a key figure in world history and in the history of salvation because he was mentioned in the Bible. European Christian literature portrayed him as an ideal knight, an exemplary king and pious Christian on a divine mission. In addition, he was also described as an obedient pupil of the Greek philosopher Aristotle, whom medieval science and philosophy venerated as a major authority. An equally popular figure in European courtly culture, Alexander became an iconic prototype of commander, conqueror, ruler, founder of an empire and civiliser. His invasion of foreign domains, perceived as distant and exotic by the European world, cast him in the role of scientific explorer and adventurer. During the crusades his legend was exploited as a political symbol of the West's victory over the East. In this context, he came to be seen as a forerunner of the ideal crusader. ${ }^{2}$ Again, during the wars against the Ottoman Empire of the fifteenth and later seventeenth centuries, Alexander once more became a symbol of the triumphant Western king subjugating the East. European princes who engaged in the wars against the Turks chose him as their heroic role model and styled themselves as new Alexanders. Especially in courtly art, his legend was a very popular motif. Yet the Christian construction of the Alexander legend in medieval Europe was ambivalent. In spite of his great popularity as a moral exemplum $^{3}$ of superbia, Alexander could equally be compared to the fallen

\footnotetext{
${ }^{1}$ According to Göller, 'Alexander und Dindimus': 105, he could never measure up to the popularity of King Arthur in Europe as a rex futurus in the medieval literary tradition though.

${ }^{2}$ Cf. Franke, 'Herrscher über Himmel und Erde': 144.

${ }^{3}$ Defined by Stoneman, 'The Legacy of Alexander in Ancient Philosophy': 326 as a 'tool of thinking'.
}

- Tfie Medieval History Journal, 11, 2 (2008): 259-287 
angel Lucifer, and portrayed as a megalomaniac, a proud, cruel and immoderate tyrant, desiring immortality and divination. Eastern medieval romances for their part depicted Alexander as a legitimate heir of the Persian Achaemenid kings, as a brave ruler and conqueror as well as a sage and prophet. Like their Western counterparts, the Eastern reincarnations of Alexander were known for their entertaining adventures and miraculous deeds.

Scholarship on Alexander III of Macedonia has invariably to deal with the problem of sources. Of contemporary sources, only a handful of coins, inscriptions and comments in some Greek orations have survived. Contemporary literary reports on Alexander's reign have only fragmentarily been cited by later authors. ${ }^{4}$ Early historical research on Alexander had focused on his personality; its main questions pertained to his character. The image of the Macedonian ruler in this scholarship ranged from that of a megalomaniac tyrant ${ }^{5}$ to the philosophical 'dreamy Boy Scout' ${ }^{6}$ seeking to realise his vision of a "unity of mankind.' ${ }^{7}$ Juridical reflections on the Macedonian constitution were additionally drawn into this research. ${ }^{8}$ The recent years have brought the realisation that in a proto-legal system like the one prevalent in Macedonia, where unwritten nomoi furnished codes of conduct, questions about institutional law could not serve as a dependable basis on which to evaluate Alexander's policies. Also, ancient characterisations of his personality cannot be treated as objective facts. The surviving sources offer little opportunity to form an understanding of his character; the diverse images they preserve are not reliable. Today, the discussion revolves principally around the structures of the Macedonian Empire; the focal points of scholarly interest are the tussle for power between the Macedonian ruler and the aristocracy with the court as political centre. ${ }^{9}$

${ }^{4}$ Cf. Baynham, 'Alexander the Great': 3-29; Bosworth, 'The Sources': 7-16.

${ }^{5}$ Cf. Badian, 'The Death of Parmenio': 324-33; Hampl, Alexander der Große; Schachermeyr, Alexander der Große.

${ }^{6}$ Holt, 'Alexander the Great Today': 111.

${ }^{7} \mathrm{Cf}$. Robinson Jr, Alexander the Great; Tarn, Alexander the Great.

${ }^{8} \mathrm{Cf}$. Wilcken, Alexander der Große; Hammond, Alexander the Great and The Macedonian State.

${ }^{9}$ Carney, Alexander the Great; Heckel, The Marshals of Alexander's Empire; Müller, Maßnahmen der Herrschaftssicherung; Wirth, Der Brand von Persepolis. 
Sources on Alexander dating back to Antiquity offer a variety of images; their judgements fluctuate between criticism and admiration. ${ }^{10}$ Alexander continued to be a controversial figure in medieval literature. Modern scholars have tried to explain the ambiguity of this image in different ways. George Cary pointed out that the theological approach to Alexander produced a negative image of the ruler as an embodiment of superbia. While Alexander was depicted as rex superbus or even an Antichrist by clerical authors, courtly writers idealised him as a brave king and gallant knight. ${ }^{11}$ Cary also spoke of a watershed between the twelfth and thirteenth centuries, in that Alexander was portrayed negatively before and received a sympathetic treatment afterwards. ${ }^{12}$ Recently, Thomas Noll has argued that the ambivalent medieval reception of Alexander depended on where the texts were composed: while Alexander enjoyed a better reputation in France and Italy, he was portrayed in German writings as a wicked tyrant. ${ }^{13}$ Such categories however appear too schematic, as most of the medieval romances portraying Alexander do so ambivalently. ${ }^{14}$ His life offered abundant material for moral examples and philosophical expositions, which furnished grounds for both admiration and revulsion. Inevitably, the medieval authors ended up casting their subject within the frame of the social, political and moral contexts of their own times. The Alexander figure was formed through the intellectual world of the author, shaped by the context of his treatment, by the writer's literary criteria and by the sources he chose to tap. ${ }^{15}$ Alexander therefore became the creation of a particular author.

${ }^{10}$ Cf. Klein, 'Alexandertopik': 180, 182, 196. Pseudo-Callisthenes heroises Alexander as world ruler; Curtius, Justin, and Orosius focus on his moral depravation; Josephus treats him favourably. Lucan, Cicero, Seneca and Valerius Maximus depict him as a brutal tyrant. Cf. Schnell, 'Der Heide Alexander im christlichen Mittelalter': 47.

${ }^{11}$ Cf. Cary, 'Alexander the Great in Mediaeval Theology': 113-14. Alexander was seen either as the first Devil campaigning against mankind before the coming of Christ or as God's instrument waging war on Persia. Cf. ibid.: 105; Franke, 'Herrscher über Himmel und Erde': 165 , note 80.

${ }^{12}$ Cf. Cary, 'Alexander the Great in Mediaeval Theology': 113-14.

${ }^{13} \mathrm{Cf}$. Noll, Alexander der Große: 19-28.

${ }^{14} \mathrm{Cf}$. Mossé, Alexander der Große: 220.

${ }^{15}$ Cf. Ehlert, 'Frauen': 103; Schnell, 'Der Heide Alexander im christlichen Mittelalter': 46-59; 'It was not Alexander's historical reality, but his significance as a symbol and as a paradigm of world rule and Gentile glory and victory' making him so popular, states van Bekkum, 'Alexander the Great in Medieval Hebrew Literature': 226.

- The Medieval History Journal, 11, 2 (2008): 259-287 
The root of medieval Alexander romances is the Greek Alexander romance, a compilation of legends, anecdotes, fairy tales and adventure stories about the famous conqueror, written by an anonymous author in third-century Alexandria and coloured by Ptolemaic ideology. ${ }^{16}$ It was erroneously attributed to Alexander's former court historiographer Callisthenes. The ultimate source of many European Alexander romances was the Latin translation of a version of Pseudo-Callisthenes' text from Constantinople by Leo the Archpresbyter of Naples ${ }^{17}$ composed in about 950. ${ }^{18}$ Also known to writers during the medieval ages was the late antique Latin translation by Julius Valerius. ${ }^{19}$ Another source for the medieval Alexander romances was the History of Alexander by the Roman writer of the first century A.D., Quintus Curtius Rufus, who highlights Alexander's corruption by fortune and portrays him as an essentially good king who turned into a ruthless tyrant. ${ }^{20}$

This article aims to explore the medieval reception of Alexander by examining one aspect of his career: his relationship with women. This dimension is integral to the medieval literary construction of Alexander as an exemplum. In a Western theological perspective, women act as an index of Alexander's morality. Warned by the philosopher Aristotle against the dangers of amor carnalis, Alexander is said to have either indulge in sin, which conforms to the image of the unrestrained tyrant, or to effectively exercise self-restraint, as was characteristic of the ideal of a chaste and moderate prince. Alexander's gentle and courtly attitude as a warrior towards conquered women is one of the central motifs in European literature and art. Portrayed as a gallant invader, Alexander was made into a symbol of magnanimity and clemency. In Western courtly romances, the focus on 'Minne' (love) is integral to the literary genre, which produced portrayals of Alexander as a knightly cavalier searching

${ }^{16}$ Cf. Baynham, 'Alexander Romance?': 1-13; Jouanno, Naissance et métamorphose du roman d'Alexandre ; Klein, 'Alexandertopik': 201; Koulakiotis, Genese; Merkelbach, Die Quellen des griechischen Alexanderromans; Wirth, 'Pseudo-Kallisthenes': 513.

${ }^{17} \mathrm{Cf}$. Southgate, 'Portrait of Alexander': 279.

${ }^{18}$ Cf. Pfrommer, Alexander der Große: 16; Stoneman, 'The Medieval Alexander': 238. Important are also the reworkings known as the Historia de Preliis (History of Alexander's battles) in three major recensions. The first was made in the eleventh century. Cf. Stoneman, 'The Medieval Alexander': 239.

${ }^{19}$ Cf. Pfrommer, Alexander der Große: 16; Stoneman, 'The Latin Alexander': 174-78.

${ }^{20} \mathrm{Cf}$. Baynham, Alexander the Great. 
for true love. But his search does not always end happily: Alexander may find his true love but he also may be betrayed by an unfaithful wife. Whereas in Western Christianity erotic adventures and carnal pleasure, even in marriage, would have detracted from Alexander's heroic perfection, the Eastern tradition casts Alexander in the role of a womaniser of sorts, allowing him polygamy and numerous love affairs.

More specifically, the article will analyse Alexander's relationship with women as it emerges in three literary variants of the Alexander romance in Western and Eastern medieval literature: the Alexandreis by the French writer Gautier de Châtillon (c.1185) which was the most influential medieval Latin epic on Alexander and enjoyed great popularity during the thirteenth century, the Alexander Romance by the German writer and diplomat Johann Hartlieb (c.1440) and the Iskandarnameh by the Persian poet Nizami (c.1191).

Gautier de Châtillon, drawn to ancient Latin poetry, consciously imitated Virgil's Aeneid. He depicts Alexander as a chaste king and philosopher. Women only play minor roles in the Alexandreis acting as signs of the ruler's self-restraint and chastity following Christian ideals. The political background of the crusades would have influenced Gautier's choice of subject. The Alexandreis presents an ideal of Christian world dominance as embodied in the personal rule of Alexander, who, in its pages, lives in accordance with Christian morals. His relationship with women is a pure metaphor of his political style. Johann Hartlieb's Alexanderroman presents an actualised conception of Alexander as Western conqueror defeating the East in the guise of a gallant courtier and adventurer. Hartlieb depicts his hero as a knightly warrior, generous ruler and cavalier who was let down finally only by his unfaithful wife. The Iskandarnameh, an example of the Eastern reception of the Alexander legend, represents a literary genre which combines political philosophy and romantic poetic tradition. The author, Nizami, confers legitimacy on the usurper and destroyer of the Achaemenid Empire: Alexander emerges in these pages as an Iranian king, sage and prophet. A world conqueror and intrepid warrior, Alexander is also a romantic hero. The women he adores are depicted mostly as independent and strong persons, but in the end it is Alexander who saves them or whom they fall in love with. Their independence is a literary device to enhance the glory of the male hero. The three constructions of the Alexander legend studied here are a source of insight into the complex literary traditions and multiple processes of

- Tfie Medieval History Journal, 11, 2 (2008): 259-287 
reception through which ancient traditions relating to the Macedonian ruler were reinvented during medieval times.

\section{Historical Precedents}

Ancient sources do not ascribe much importance to the love affairs of Alexander the Great. The evidence barely refers to this subject and generally creates the impression that his interest in women was limited, that he had some interest in men ${ }^{21}$ and mostly in power. ${ }^{22}$ Traditions hostile to the ruler interpreted this lack of interest in the female sex as sign of inadequate masculinity; more favourable traditions read this a form of effective self-control. ${ }^{23}$

Alexander's mother Olympias seemed to be the only woman he was close to. ${ }^{24}$ She was believed to have considerable influence over him and his politics. Historically, Olympias certainly was the most important woman in Alexander's court and remained influential in Macedonian politics after his departure for Asia and even after his death. ${ }^{25}$ Plutarch and Justin report that many blamed Olympias and Alexander for the death of Philip II in 336 B.c. and suspected them of having engineered his murder because Philip's last marriage to a Macedonian noble girl had posed a threat to Alexander's succession. ${ }^{26}$ This tradition however needs to be viewed with caution. By the time of Philip's death, he (Philip) had publicly reconciled with his son and Olympias. ${ }^{27}$

Apart from his mother, there are few other women mentioned in the ancient sources on Alexander's career. After her capture in 333 B.c. he seems to have entered into a relationship with Barsine, daughter of a Persian noble and a Greek woman. ${ }^{28}$ She bore him a son called Heracles

${ }^{21}$ Athen. 13,603 A.

${ }^{22}$ Cf. Carney, 'Women in Alexander's Court': 227-52.

${ }^{23}$ Plut. mor. $1099 \mathrm{C}-\mathrm{D}$.

${ }^{24}$ Cf. Koulakiotis, Genese: 205.

${ }^{25}$ Plut. Alex. 39.7, mor. 180 D; Diod. 17.118.1; 19.11; Just. 12.14.3-4; Arr. an. 7.12.5-7; Athen. 13.560 F. Cf. Carney, 'Women in Alexander's Court': 233-40. Probably, she held a position of authority during her son's reign as a counter-weight to the noble opposition in Macedonia.

${ }^{26}$ Plut. Alex. 9.4-6; Athen. 13.557 D-E; Just. 9.7.3-10.

${ }^{27}$ Plut. mor. $179 \mathrm{C}$; Just. 9.7.10.

${ }^{28}$ Plut. Alex. 21.4; Eum. 1.3 Cf. Carney, 'Women in Alexander's Court': 243-45. 
who was killed during the wars of the successors. ${ }^{29}$ Late in his reign Alexander married three Persian women: in 327 the Bactrian Roxane, in 324 the Achaemenid princesses Stateira, daughter of Darius III and finally Parysatis, daughter of Artaxerxes III. ${ }^{30}$ The marriage alliances with the Achaemenid brides were part of his propaganda addressed to the Persians, with a view to claiming legitimacy and emphasising the continuity of Persian traditions. ${ }^{31}$ To this end, he also treated the captured mother, wives and daughters of Darius III with generosity, as if they were his own family. ${ }^{32}$ They were dynastic tokens which allowed him to take the place of Darius within the Achaemenid family. In Alexander's afterlife, this episode provided an example of his clemency, continence and self-restraint. ${ }^{33}$ Exemplifying his magnanimity, ${ }^{34}$ medieval texts treated Alexander as a model of political self-fashioning and as an exemplum of virtue, ascriptions that later found expression in Renaissance and Baroque art. European princes and kings strove to emulate Alexander as a model of a gentle and courtly conqueror. ${ }^{35}$ In effect the figure became increasingly removed from his original context and now came to serve as a foil for other ambitions and ideals. ${ }^{36}$

Another famous tale making up the legend was Alexander's encounter with the Amazon queen Thalestris. The story appears in all our main Alexander sources and Greek recensions of the Alexander romances, as well as in the Latin text of Julius Valerius. ${ }^{37}$ According to the major tradition Thalestris came to Alexander to conceive a child by an invincible

${ }^{29}$ Curt. 10.6.11; 10.6.13.

${ }^{30}$ Arr. an. 7.4.4. Macedonian rulers were polygamous. It is suggested that polygamy was a Macedonian royal tradition even before the reign of Philip II.

${ }^{31}$ Plut. mor. 338 D; Curt. 10.3.12.

${ }^{32}$ Arr. an. 2.12.3-8; Curt. 3.12.10-26; Val Max. 4.7.ext. 2A; Diod. 17.37.

${ }^{33}$ Cf. Cary, The Medieval Alexander: 218.

${ }^{34}$ Cf. Ehlert, 'Frauen': 97; Franke, 'Herrscher über Himmel und Erde': 122, 143.

${ }^{35} \mathrm{Cf}$. Franke, 'Herrscher über Himmel und Erde': 121.

${ }^{36}$ According to George Cary, with the establishment of courtly convention it became necessary to create an amorous Alexander in medieval romances. Cf. Cary, The Medieval Alexander: 219.

${ }^{37}$ Cf. Baynham, 'Alexander and the Amazons':115, note 2; Stoneman, The Greek Alexander Romance:143-45; Noll, Alexander der Große: 34-36. The sole exception is the Metz Epitome, a late text (ca. 4th-5th century AD). For the Amazon as a symbol of female knightly heroism see Franke, 'Herrscher über Himmel und Erde': 134.

- The Medieval History Journal, 11, 2 (2008): 259-287 
father. ${ }^{38}$ Though the historicity of the Amazon tale was doubted even in Antiquity, it probably satisfied the expectations of the ancient audience, who believed that all of the famous Greek heroes like Perseus, Heracles and Achilles had encountered Amazons. ${ }^{39}$ As Alexander claimed descent from Achilles, one could suggest that an encounter of the 'new Achilles' and the Amazons was expected in the Greek and Macedonian world. ${ }^{40}$ The construction of Alexander as primarily a youthful hero led him to be viewed in the ancient world as a soldier, adventurous conqueror and commander. The Achilles motif features in both historical accounts and in iconography. ${ }^{41}$ Traditionally, the typical ancient youthful hero sets out in the direction of foreign places and dies young, single and childless. In the eyes of the Greeks and Macedonians, to whom these legends were addressed, he needed no woman at his side, apart from his mother Olympias who was cast in the role of Achilles' mother Thetis. His life partner was his boyhood friend Hephaistion who was represented as a second Patroclus, Achilles' mate, and further sustained the Achillean link. ${ }^{42}$ That the Patroclus motif symbolised a love affair of Hephaistion and his new Achilles was evident to Alexander's contemporaries. ${ }^{43}$

\section{Gautier de Châtillon, Alexandreis: Revising Curtius}

Gautier de Châtillon, otherwise called Gautier de Lille, wrote the most popular of all medieval Latin epics on Alexander, ${ }^{44}$ a hexameter poem in ten books dedicated to his patron Guillaume, the archbishop of Reims. ${ }^{45}$

${ }^{38}$ Plut. Alex. 46.1; Curt. 6.5.25-32; Diod. 17.77.1-3; Strab. 11.5.4; Just. 12.3.5-7; Arr. an. 7.13.2-6; Ps.-Call. 3.25-27. In the Greek Alexander romance the Amazons are permitted into his camp but Alexander does not sleep with their queen.

${ }^{39}$ According to Plut. Alex. 46.1-3 Alexander wrote in a letter to Antipater that the Scythian king offered him his daughter in marriage but he makes no mention of the Amazons.

${ }^{40}$ Cf. Baynham, 'Alexander and the Amazons': 116; Ehlert, 'Frauen': 99-102; Koulakiotis, Genese: 205. Baynham suggests that the tale was part of Alexander's original propaganda illustrating that he followed his heroic ancestors.

${ }^{41}$ Cf. Müller, 'Alexander der Große als neuer Achilles': 263-94.

${ }^{42}$ Arr. an. 1.12.1; Ael. v.h. 12.7. Cf. Just. 12.12.11-12; Lukian Calumn. 17; dial. Mort. 12.4 .

${ }^{43}$ Aischin. 1.133. 142-44.

${ }^{44} \mathrm{Cf}$. Orth, 'Magnus in exemplo est': 1 . He calls it a 'bestseller'.

${ }^{45}$ Cf. Cary, 'Alexander the Great in Mediaeval Theology': 63; Destombes, 'The Mappamundi': 11; Mossé, Alexander der Große: 220; Tilliette, 'Gautier': 275. 
It was composed between 1176 and $1201 .{ }^{46}$ Gautier's principal source was the Histories of Curtius. ${ }^{47}$ In fact, long passages of the Alexandreis versify Curtius's text which was otherwise not read widely in Châtillon's times. ${ }^{48}$ The Histories actually did not play a major part in the development of the Alexander legends until the appearance of Alexandreis. ${ }^{49}$ Gautier also drew upon Justin, Josephus, Lucan and Julius Valerius. ${ }^{50}$ In the tradition of the carmen heroicum he shaped his Alexandreis on the pattern of Virgil's Aeneid and created a popular text, which was then conserved through some 210 copies made during the thirteenth century. ${ }^{51}$ Gautier's text was addressed primarily to intellectual courtly circles: it was written in Latin and suppressed the most popular legendary tales of Alexander which recounted his journey to heaven in the gryphon chariot (borne by eagles in an earlier version) and his underwater expedition in a diving bell. ${ }^{52}$

Born near Lille about 1130/40, Gautier studied theology in Paris and Reims, worked as a teacher in Châtillon and Bologna and returned to France as secretary of archbishop Henri of Reims and his successor Guillaume. ${ }^{53}$ As his patron was of royal descent and Philippe II Auguste took part in the third crusade by the time of the composition of the Alexandreis (1190/91), it is probable that the poem had a political dimension of portraying the victory of the West over the East. ${ }^{54}$

${ }^{46}$ Cf. Harich, Alexander Epicus: 5.

${ }^{47}$ Cf. Cary, The Medieval Alexander: 173; Glock, 'Alexander Gallicus?': 280-97; Orth, 'Magnus in exemplo est': 1; Pfrommer, Alexander der Große: 17; Stoneman, 'The Medieval Alexander': 241; Wiener, Proles: 17, 19, 25-32; Wulfram, 'Übergang': 47.

${ }^{48} \mathrm{Cf}$. Orth, 'Magnus in exemplo est': 2; Tilliette, 'Gautier': 276, note 4.

${ }^{49} \mathrm{Cf}$. Stoneman, 'The Medieval Alexander': 241 . As great parts of his text were already lost in late Antiquity, Gautier had to rely on supplements composed by later authors. Cf. Wulfram, 'Übergang': 47-48. Book 1 and 2 of Curtius's Histories are completely lost and parts of book 3, 5, 6 and 10 are missing.

${ }^{50} \mathrm{Cf}$. Cary, The Medieval Alexander: 63.

${ }^{51}$ Cf. Harich, Alexander Epicus: 136; Tilliette, 'Gautier': 275.

${ }^{52}$ Cf. Loomis, 'Alexander the Great's Celestial Journey': 136-40, 177-83; Noll, Alexander der Große: 10-18; Schmidt, A Legend and its Image.

${ }^{53}$ Cf. Harich, Alexander Epicus: 9.

${ }^{54}$ Cf. Destombes, 'The Mappamundi': 11; Harich, Alexander Epicus: 245-48. Orth, in 'Magnus in exemplo est'(p. 4) seems hesitant about his theory. It is unclear whether the poem was commissioned on the occasion of an artistic competition at Reims or whether Gautier had fallen from grace and tried to regain the archbishop's favour with this text.

- The Medieval History Journal, 11, 2 (2008): 259-287 
In any case, Gautier stresses the moral lessons Alexander learnt at the school of the philosopher Aristotle. This is of course one of the most popular Alexander themes in medieval texts because of the great interest in Aristotle, a major intellectual authority of the time. The medieval Alexander romances ascribed great prominence to Aristotle and substituted Philip and Parmenion as father figures and advisers. The historical figure, Aristotle, was chosen by Philip II as tutor of his son but it is unclear how much influence he really exerted on Alexander. ${ }^{55}$ Judging from his politics, Alexander cared little for Aristotelian philosophy. Plutarch states blankly that he ignored Aristotle's advice to subdue the Eastern 'barbarians'. ${ }^{56}$ Moreover, there is some evidence for an estrangement between Alexander and his former tutor. Plutarch even cites some sources claiming that Aristotle took part in the final conspiracy against Alexander's life. ${ }^{57}$ As a friend of Antipater's Aristotle allegedly fetched the strong poison Alexander fell victim to at his last banquet when he was murdered by the sons of Antipater, Cassander and Jollas. ${ }^{58}$ However, Plutarch doubts whether this tradition is reliable. ${ }^{59}$ In any case, Alexander was depicted in ancient sources either as a philosopher king or as a great disappointment to his tutor. ${ }^{60}$

Aristotle as moralist figures prominently in a tradition of the Alexander Romance that only emerged in the Medieval Ages: the story of the poisonous girl. ${ }^{61}$ It is recounted in the Secreta secretorum (Secret of Secrets), an original Arabic text that was translated into Latin during the twelfth century, and claimed to be a letter of advice on kingship from Aristotle

Cf. Harich, Alexander Epicus: 7. Gautier died of plague at Amiens. Cf. Destombes, 'The Mappamundi': 11.

${ }_{55}^{5}$ Plut. Alex. 7-8. Cf. Brocker: Aristoteles; Koulakiotis, Genese: 74-76.

${ }^{56}$ Plut. mor. 329 B.

57 Plut. Alex. 77.2.

${ }^{58}$ Plut. Alex. 76.2-3; Just. 12.14.7; Arr. an. 7.27.1-2; Ps.-Call. 3.31.5-9.

${ }^{59}$ Plut. Alex. 77.3.

${ }^{60} \mathrm{Cf}$. Koulakiotis, Genese: 59-84.

${ }^{61}$ Cf. Hertz, 'Die Sage vom Giftmädchen': 195; Stoneman, 'The Medieval Alexander': 250, note 11. In the nineteenth century, Nathaniel Hawthorne adopted the story for his Gothic novel Rappacini's Daughter. In his version, a famous Italian physician styled as 'mad scientist' uses his daughter for an experiment. Throughout her childhood and youth she breathes in the odour of poisonous crops in his garden. In consequence, she becomes poisonous herself and is able to kill anybody with her breath or her touch.

The Medieval History Journal, 11, 2 (2008): 259-287 
to Alexander. ${ }^{62}$ This is a key work for the medieval image of Alexander. ${ }^{63}$ According to the narrative, Aristotle warns Alexander against touching a beautiful girl sent to him as a gift by the queen of India. The philosopher becomes aware of the danger when he recognises her unchaste and imprudent glance. He proves to be right as the dangerous creature could kill anybody by her kisses. Thanks to Aristotle's warning Alexander could escape her lethal seduction. ${ }^{64}$ The tale enjoyed great popularity and was cited often and in several versions. ${ }^{65}$ Far from being read as a slur on Alexander's chastity, it showed him up as capable of restraint. ${ }^{66}$

Guillaume de Châtillon portrays the pagan philosopher Aristotle as a medieval cleric. Aristotle counsels Alexander on royal behaviour before he departs for his military campaigns in Greece. The philosopher insists that Alexander not give in to drunkenness and carnal sin but carry on with living in chastity. He should not let his heart be broken by love, characterised as the disease of the soul, and should serve neither Bacchus nor Venus, for this would mean sacrificing his freedom of will and becoming a slave of his vices. ${ }^{67}$ Of course, self-restraint had also been one of the major virtues in Antiquity but this advice was certainly not one Aristotle might have given to a Macedonian ruler as it reflects Christian morals and thoughts. Gautier's purpose was to create an Alexander figure that excelled in self-restraint and chastity during his career, as a result of following such advice.

How much of Curtius' criticism of Alexander was incorporated by Gautier in his epic is a matter of debate. Despite some ambivalent tendencies in the Alexandreis, George Cary, Henriette Harich and Clause Mossé

${ }^{62}$ Cf. Hertz, 'Die Sage vom Giftmädchen': 156-57, 164; Stoneman, 'The Medieval Alexander': 247-48; Ryan and Schmitt, Pseudo-Aristotle; Wisbey, Alexanderbild: 104.

${ }^{63}$ Cf. Cary, The Medieval Alexander: 64; Hertz, 'Die Sage vom Giftmädchen': 164; Stoneman, 'The Medieval Alexander': 48.

${ }^{64}$ Cf. Hertz, 'Die Sage vom Giftmädchen': 162, 167, 195. In the Arabian text it is her kiss combined with sexual intercourse that is lethal. Cf. Penzer, Poison-Damsels: 3-71.

${ }^{65} \mathrm{Cf}$. Hertz, 'Die Sage vom Giftmädchen': 167. In one variation, she became poisonous because she was brought up by a snake. Alternatively, her mere glance is lethal. In some versions, Alexander tests her on a condemned prisoner.

${ }^{66}$ Cf. Cary, The Medieval Alexander: 100.

${ }^{67}$ Alexandreis, I 164-173. Cf. Harich, Alexander Epicus: 205; von Châtillon, Das Lied von Alexander dem Großen.

- The Medieval History Journal, 11, 2 (2008): 259-287 
all argue in favour of a heroic image of Alexander as an ideal knight. ${ }^{68}$ Dennis Kratz, on the contrary, makes a radical suggestion by calling this text a 'mocking epic'. In his view, Gautier wrote a parody of Alexander's heroism based on Lucan's Pharsalia, which he mentions in the Alexandreis. ${ }^{69}$ The Roman poet Lucan, a stern opponent of monarchy, depicts Alexander as a megalomaniac, bloodthirsty mass murderer and tyrant who terrorised the world, in short, as wickedness incarnate. ${ }^{70}$ JeanYves Tilliette suggests that the picture of Alexander is ambiguous in the Alexandreis. He is cast as a generous but not ideal king because of his lack of clerical wisdom. For Tilliette, Gautier's ambivalent treatment of the Alexander figure reveals a 'tragic denouement rather than triumph, suggesting that heroism is ... ultimately self-destructive. ${ }^{71}$

Compared to Curtius's Histories, it is clear that Gautier has internalised the critique of superbia, of decadent joy in Persian luxury and of striving for apotheosis, although he does not express these points explicitly in the Alexandreis. ${ }^{72}$ Apart from this, Alexander has been stripped of all the negative attributes Curtius attaches to him. Specifically, Gautier suppressed Curtius's criticism of Alexander's sexual depravity. These omissions cast light upon the medieval author's particular interests, approaches and aims, and his processes of selection are telling. In this context, it is important to consider that the ethical and moral element is an important feature in medieval Alexander romances and that Gautier's audience had expectations and views about Alexander that were very different from those of their counterparts in Antiquity.

In Curtius's Histories Alexander is anything but chaste. The author's moral injunctions pertaining to Alexander's character are clearly marked

${ }^{68}$ Cf. Cary, The Medieval Alexander: 173; Harich, Alexander Epicus: 246; Mossé, Alexander der Große: 220. See also Pfrommer, Alexander der Große: 17.

${ }^{69}$ Alexandreis, V 507. Cf. Kratz, Mocking Epic: 61-155; Tilliette, 'Gautier': 278-79, 286, note 30 .

${ }^{70}$ Luc. Phars. 10.20-52. Cf. Sen. ep. 91.17. For Wiener, Proles: 48 and Wulfram, 'Übergang': 46, Gautier mainly adopts the concept of the translatio imperii from Lucan. In consequence, Gautier implies that the Macedonian Empire substituted the Persian Empire.

71 'dénouement tragique, et non pas triumphal, suggère que l'héroïsme est ... au bout du compte, auto-destructeur'. Tilliette, 'Gautier': 286. Cf. Orth, 'Magnus in exemplo est': 5.

${ }^{72}$ Alexandreis, III 241-57. Cf. Wisbey, Alexanderbild: 56-57.

The Medieval History Journal, 11, 2 (2008): 259-287 
by the topoi of decadence. He accuses him of undergoing a change of character ensuing from the corrupting power of fortune; this aspect, which followed the conquest of Asia and his assumption of Persian kingship, has been rendered in an extremely negative tone. According to the moralising Roman tradition, decadence was originally an Eastern vice whose manifestations included luxuria, copia, superbia, avaritia and inmoderatio. ${ }^{73}$ When Alexander and the Macedonians conquered Asia, they contracted Persian vices and became decadent themselves. Alexander's defeat therefore was a consequence of his own weakness that came from adopting Persian customs. ${ }^{74}$ Following this change in character, Curtius depicts Alexander as an oriental tyrant who had lost control over his passions: his depravity is illustrated by his alcoholism, by his invitation of hetairai to his banquets and by his erotic adventures. ${ }^{75}$ Alexander's alleged affair with the Amazon queen must have been especially shocking for Curtius as Thalestris was a barbarian in his eyes, more so than the Macedonians were in Roman eyes. ${ }^{76}$

Since Christian morality viewed homosexuality as a grave sin, Gautier had to carefully suppress any reference to the homoerotic that may have crept into his sources. ${ }^{77}$ Curtius provides an abundance of details that would have contradicted Gautier's image of Alexander as a king adhering to Christian morals. For instance, Curtius indicates that Alexander's boyhood friend Hephaistion was his life-long love, that Alexander was attracted to a beautiful young man named Elpinikos and that he adopted the harem of Darius containing women and catamites. ${ }^{78} \mathrm{He}$ also treats Alexander's affair with the eunuch Bagoas at length as a further example of his moral depravity. ${ }^{79}$ Gautier duly ignores all such information. In the Alexandreis, Bagoas is only referred to once and treated with conspicuous brevity. According to Curtius the Persian satrap Nabarzanes had revolted against

${ }^{73}$ Sall. Cat. 10.6; 11.4-8; 13.3; Cic. Cat. 2.2.25; Liv. 36.11.1-4. Cf. Müller, 'Luxus, Sittenverfall, Verweichlichung und Kriegsuntüchtigkeit': 37-40.

${ }^{74}$ Curt. 6.2.1-2. This is plainly expressed in his verdict that Alexander was not defeated by Persian weapons but by his own vices.

${ }^{75}$ Curt. 5.7.1-3; 6.2.1-6; 6.6.1-2.

${ }^{76}$ Curt. 6.5.30-32.

${ }^{77}$ Cf. Ehlert, 'Frauen': 102-3; Harich, Alexander Epicus: 212.

${ }^{78}$ Curt. 3.12.16; 7.9.19; 6.6.8.

${ }^{79}$ Curt. 10.1.25-42. Cf. Baynham, Alexander the Great: 170; Müller, Maßnahmen: 199-201.

- The Medieval History Journal, 11, 2 (2008): 259-287 
the Macedonian conquest and tried to become reconciled with Alexander by sending him the beautiful young eunuch Bagoas as a gift. Bagoas used to be one of Darius' favourites and soon became Alexander's lover. ${ }^{80}$ Gautier reduces this historical record of their relationship to one single short comment: the wimpish and flaccid Bagoas begged for Nabarzanes' life. ${ }^{81}$ Interestingly, Gautier also omits references to homosexual relationships of other Macedonians. Curtius narrates that the conspirator Dimnus who planned to plot against Alexander was supported by his lover and that the page Hermolaus too instigated a conspiracy together with his boyfriend. ${ }^{82}$ Gautier distances himself from such narratives carried by his main source. In his view a man-centred knightly world of war and adventure like the travelling court of Alexander had to be imagined as a heterosexual sphere.

The fact that Gautier does not pay much attention to women in his Alexandreis, therefore, cannot be explained by his use of Curtius as the main source, who actually does mention women at Alexander's court. ${ }^{83}$ Gautier tends to refer precisely to women in Alexander's career whom he does not fall in love with. The encounters with these women emphasise his virtues of moderatio, pietas, pudor and constantia. The most illustrious example is Alexander's noble treatment of the captured female family members of Darius whose virtue he respects. ${ }^{84}$

\section{Johann Hartlieb's Alexanderroman: Mother Figures and an Unfaithful Wife}

The German teacher and diplomat Johann Hartlieb translated the Latin Alexander romance into German in about 1440, bestowing on the narrative a courtly character. ${ }^{85}$ The sources he drew upon included Leo of Naples, the Historia de Preliis and the Epitome of Julius Valerius. ${ }^{86}$ Thanks to the invention of the letterpress, Hartlieb's Alexanderroman became

${ }^{80}$ Curt. 6.5.23; 10.1.25-29. Cf. Plut. Alex. 67.4; Athen. 13.603 A-B. Bagoas stayed at Alexander's court until his death in Babylon (Ael. v.h. 3.32).

${ }^{81}$ Alexandreis, VIII 6-7.

${ }^{82}$ Alexandreis, VIII 79-110; VIII 250-55. Cf. Curt. 6.7.2-15; 6.10.11-18; 8.6.7-9.

${ }^{83}$ As is suggested by Harich, Alexander Epicus: 202-3.

${ }^{84}$ Alexandreis, III 235-39.

${ }^{85}$ Cf. Lechner-Petri, 'Leben und Werke': $3,8$.

${ }^{86}$ Cf. ibid. : 10. Hartlieb was born around 1400 and studied in Vienna. 
the most popular Alexander romance in fifteenth-century Germany. In his text, Hartlieb highlights the role of Alexander's mother Olympias and stresses the love between mother and son. ${ }^{87}$ She is the most important woman in his life: in the midst of the Persian war Alexander suddenly returns home to see and speak to his 'dear mother', ${ }^{88}$ while according to the historical account, Alexander never saw her again after leaving Macedonia.

All the women Alexander meets in Hartlieb's Alexanderroman are either cast in the roles of substitute royal mothers (like queen Candacis and Darius' mother Sisygambis) or are portrayed as substitute sisters (like Darius' wife Stateira). The example of Candacis is instructive in understanding Hartlieb's approach to his subject. In most medieval Alexander romances Candacis and Alexander fall in love with each other and consummate a passionate affair. ${ }^{89}$ In the Greek Alexander romance, however, there is no suggestion of a relationship of this kind between them. Candacis of Meroe is described as a proud, wise and beautiful middle-aged queen living in the former territory of the legendary Semiramis. Appearing in her regal costume she reminds Alexander of his mother. ${ }^{90}$ Hartlieb follows this historical tradition. His Alexander figure is also reminded of his mother while watching Candacis and she feels for him like for a son. ${ }^{91}$

There are three exceptions to the rule by which Hartlieb cast his female figures in the role of either substitute mothers or sisters: the Indian queen

${ }^{87}$ Hartlieb, Alexanderroman: P. 59, 1. 5-7.

${ }^{88}$ Hartlieb, Alexanderroman, P. 58, 1. 22-25.

${ }^{89}$ Cf. Cary, The Medieval Alexander: 219-20; Schnell, 'Der Heide Alexander im christlichen Mittelalter': 89-90. For instance, in Ulrich von Etzenbach's Alexander, from about 1270-87, relying on Gautier de Châtillon and the Historia de Preliis, Candacis and Alexander are depicted according to the literary conventions of medieval love poetry. They exchange intimate letters and fall in love with each other before they even meet. Candacis is sad when Alexander informs her about his marriage to Roxane. When they finally meet they overcome all obstacles and end up as lovers.

${ }^{90}$ Ps. Call. 3.18.1-23.7. Only in an Ethiopian version of the Greek Alexander romance does Alexander sleep with her. Cf. Baynham, 'Alexander Romance': 3, note 16. The regal title of the queens of Meroe (ktke) was mistaken for a female name (Kandake) by Greek and Roman writers. Cf. Hofmann, Beiträge zur meroitischen Chronologie.

${ }^{91}$ P. 150, 1. 30-p. 151, 1. 4; p. 157, 1. 7-8. For Ehlert, 'Frauen': 91-92, Hartlieb had to avoid any sexual encounters as he had presented Candacis as a chaste and honourable woman. Therefore, Alexander had to respect her chastity.

- The Medieval History Journal, 11, 2 (2008): 259-287 
Cleophilis, the Amazon Thalestris and Roxane. Cleophilis deploys a sexual episode with Alexander as a stratagem to regain control of her former territory. ${ }^{92}$ Thalestris and her female troops come to Alexander's camp to conceive children by him and his Macedonian soldiers. Alexander, in Hartlieb's account, lets them stay for one month, but like Gautier before him, the author carefully avoids furnishing details about their relationship..$^{93}$ The Amazon tale in the German Alexanderroman serves to underline Alexander's courtly treatment of women in general. Contrary to the advice of his inner circle to wage war against the Amazons, the Macedonian ruler declares violence against women as shameful. ${ }^{94}$ Hartlieb possibly wished to imply that Alexander had promised help to the Amazon queen before she told him about her special wish. As an honest knight he was then obliged to keep his promise although this meant committing adultery. ${ }^{95}$

The last exception to Hartlieb's cast of female protagonists is Roxane. Hartlieb emphasises that Alexander married the daughter of Darius in keeping with a promise made to the king on his deathbed. ${ }^{96}$ In keeping with his virtues as a knight and gentleman he afforded his wife no reason for complaint, while Roxane turned out to be unfaithful to her husband. Hartlieb is the only author of an Alexander romance to charge her with adultery; this would appear to be an evident transfer to Roxane of the image of an unfaithful wife, originally ascribed to Olympias. ${ }^{97}$ Being the most important female figure in Hartlieb's romance, Alexander's mother was presented as a chaste and honourable woman. The Alexanderroman

${ }^{92}$ Hartlieb, Alexanderroman, P. 113, 1. 10-15. Cf. Just. 12.7.9-11; Curt. 8.10.35-36. Ancient sources call her Cleophis. Justin criticises her behaviour harshly, accusing her of prostitution. Curtius merely reports that she could win back her territory because of her beauty but hints that she might have spent the night with Alexander as she gives her son his name. The child was born soon after Alexander's visit. Hartlieb (p. 113, 1. 10-15) treats the queen rather neutrally.

${ }^{93}$ Hartlieb, Alexanderroman, P. 170, 1. 1-6. Cf. Harich, Alexander Epicus: 204. She is seen as a necessary tribute to the expectations of the audience.

${ }^{94}$ Hartlieb, Alexanderroman, P. 167, 1. 20-21.

${ }^{95}$ Cf. Schlechtweg-Jahn, 'Hybride Machtgrenzen in deutschsprachigen Alexanderromanen': 283.

${ }^{96}$ P. $104,1.20-28$.

${ }^{97}$ P. $269,1.18-27$. It was Hartlieb's original contribution but it is unknown whether it was his own invention. Cf. Lechner-Petri, 'Quellen und Übersetzungstechnik': 16. 
plays down the famous episode to be found in the Greek Alexander romance wherein Olympias was seduced by the last Egyptian Pharaoh and magician Nectanebo II, disguised as the god Ammon. ${ }^{98}$ Whereas PseudoCallisthenes confirms that Olympias knowingly committed adultery and continued her relationship with her 'divine lover', she emerges in Hartlieb's account as having been forced into infidelity by the magic power of her seducer. ${ }^{99}$ In addition she deeply regretted her unfaithfulness. ${ }^{100}$

According to Hartlieb, Roxane had love affairs with several men while Alexander was waging war, making it difficult for him to ascertain which of her children were fathered by him. ${ }^{101}$ As a result, even possibly legitimate children were charged with bastardy. ${ }^{102}$ This is Hartlieb's explanation for why Alexander left his empire without an heir, thereby leaving it to fall into chaos. ${ }^{103}$ The question of continuity was evidently central to monarchical systems; the purpose of royal marriages was procreation to produce heirs. Even in Antiquity, Alexander's lack of interest in forming marriage alliances was critiqued as a sign of indifference to the problem of succession: neglect of a central regal obligation cast a shadow on his image as a king and politician. Hartlieb therefore saw himself confronted with the task of whitewashing this image so as to be able to recast Alexander as an ideal for kings and courtiers to pattern their political self-fashioning. In the Alexanderroman the explanation for the Macedonian king's failure to secure succession was laid at the door of his unfaithful sinning wife. Roxane, in other words, comes to be cast into the stereotypical role of the unfaithful wife, while Alexander-and indeed his empire-was portrayed as the victim of her wantonness. ${ }^{104}$

The episode of Roxane's adultery is preserved only in Hartlieb's Alexanderroman. Ancient Greek sources and Latin translations of the

${ }^{98}$ Ps.-Call. 1.4-7. Therefore, Alexander allegedly was his son. Cf. Carney, Olympias: 26, 111; Jasnow, 'The Greek Alexander Romance and Demotic Egyptian Literature': 95-103; Koulakiotis, Genese: 199-202; Merkelbach, Die Quellen des griechischen Alexanderromans: 57-60; Stoneman, The Greek Alexander Romance: 11-12.

${ }^{99}$ Cf. Ehlert, 'Frauen': 95-96.

${ }^{100}$ The tale on Alexander's divine descent was mentioned by Plut. Alex. 3. Some of his sources claim that Olympias confided the secret of Alexander's 'real descent' to him before he departed for Persia.

${ }^{101}$ Hartlieb, Alexanderroman, P. 271, 1. 25-p. 272, 1. 10.

${ }^{102}$ Ibid. P. 272, 1.1-6.

${ }^{103}$ Ibid. P. 272, 1. 14-15.

${ }^{104}$ Ibid. P. 272, 1. 5.

- The Medieval History Journal, 11, 2 (2008): 259-287 
Greek Alexander romance did not carry suggestions that would have cast a shadow of doubt on her sexual fidelity. In the Liber de morte, she is treated as a caring wife who even prevents Alexander from committing suicide in his last days: it is she who dragged her husband away from the Euphrates where he tried to drown himself in the wake of cruel torture and poisoning. ${ }^{105}$ Hartlieb paraphrases the story by stressing that Alexander had not intended to put an end to his life, but pretended to do so in order to protect Roxane and her children from harm, and instead of dying he disappeared mysteriously. In addition he reassures his unfaithful wife of his great love and praises her chastity. ${ }^{106}$ Hartlieb's portrait of Roxane can be assimilated to the literary topos of 'Weiberlisten' (the intrigues of women) while Alexander comes to be cast in the role of the 'Minnesklave' (slave to love). ${ }^{107}$ In an earlier German version of the Alexander romance, composed at the end of the thirteenth century by Ulrich von Etzenbach, Roxane was portrayed as a disloyal wife, though not sexually: the narrative contains no reference to adultery; rather it holds her responsible for letting go of the chain of Alexander's diving bell when he descended down to the sea, as a way of seeking revenge for her father's (Darius) death. ${ }^{108}$ For Trude Ehlert, the most likely explanation of the story of Roxane's adultery was that Hartlieb intended to illustrate that quality and success of rule did not exclusively depend on the ruler's morals but also on the morals of his subjects. ${ }^{109}$ Hartlieb sought to explain why the Argead dynasty collapsed, why the wars of succession broke out, why one of the most famous conquerors in history failed to secure his conquests, and why his empire collapsed so rapidly after its creation. The answer to all these complex problems was a simple one: a woman was to blame. There is little doubt that Hartlieb was influenced by biblical images of sinful women. He might also have had in mind the legendary and beautiful Helen of Troy who was believed to have caused the great war between Greece and Troy.

${ }^{105}$ Liber de morte 101-02; Arr. an. 7.27.3. Ps.-Call. 3.32.1 reports that she helped him to leave his last banquet when he fell ill. Cf. Baynham, 'Alexander Romance': 5.

${ }^{106}$ P. 265, 1. 6-13.

${ }^{107}$ Cf. Noll, Alexander der Große: 22.

${ }^{108}$ von Etzenbach, Alexander: p. 645, 1. 24258-24269. Cf. Noll, Alexander der Große: 22.

${ }^{109}$ Cf. Ehlert, 'Frauen': 98-99.

The Medieval History Journal, 11, 2 (2008): 259-287 
In Greek historical accounts, Roxane remains a shadowy figure, fading from the limelight soon after her wedding. As Alexander's queen she remained an obscure person throughout her time and played only a limited role in his court. Marrying her had been more of a diplomatic expediency, perhaps even a last desperate measure by Alexander to curtail the revolts in Bactria and Sogdiana. ${ }^{110}$ Persian resistance to the Macedonian conquest had been sustained, almost forcing Alexander's troops to retreat. Albert Brian Bosworth has pointed out that a whole year is missing in the official historiography of Alexander's Persian wars. It is exactly the year 328 в.C. when the Persian revolt reached its climax and nearly put an end to the Macedonian rule of Persia. ${ }^{111}$ But Alexander managed to divide the Bactrian opposition through his marriage alliance with Roxane. This was a lesson he had learned from his father Philip who married seven wives to seal existing alliances or create new ones, so as to stabilise his empire and secure its borders. ${ }^{112}$ Alexander followed this example: Roxane was the daughter of a Bactrian noble and the prime purpose of the marriage was to pacify remaining resistance in Bactria. In fact, Alexander's strategy succeeded in that he obtained the support of the allies of his new fatherin-law and the revolt lost its explosive effect. ${ }^{113}$ The benefit certainly outweighed the disadvantages, as the Macedonians raised strong objections to the wedding, frowning upon their ruler's marriage to a captive Asian woman. ${ }^{114}$ Curtius' history adopts the Macedonian perspective, recounting the event in a hostile tone that expressed a critique of Alexander having forgotten his Macedonian roots. ${ }^{115}$ Roxane lost her symbolic aura as soon as the Bactrian revolt came to an end; Alexander kept his distance from her and married two Achaemenid princesses in 324 B.c. She however regained importance after Alexander's sudden death, when she was pregnant with his only legitimate son. ${ }^{116}$

The question remains why the historical Alexander betrayed little concern about a successor except in the last phase of his reign. According

${ }^{110}$ Just. 12.12.2-3; Arr. an. 4.19.5-6; Curt. 8.4.29-30; Plut. Alex. 47.4. Cf. Müller, Maßnahmen: 61-62; Wiesehöfer, Persien: 151.

${ }^{111}$ Cf. Bosworth, 'A Missing Year': 17-39.

112 Athen. 13,557 B-E. Cf. Carney, Olympias: 21.

${ }^{113} \mathrm{Cf}$. Wiesehöfer, Persien: 151.

${ }^{114}$ Curt. 8.4.29; 10.6.13-16. Cf. Baynham, Alexander the Great: 125.

${ }^{115}$ Curt. 8.4.23-30. Cf. Carney, 'Women in Alexander's Court': 246.

${ }^{116}$ Curt. 10.6.9.

- The Medieval History Journal, 11, 2 (2008): 259-287 
to Plutarch, Alexander rejected the advice of the Macedonian nobles Parmenion and Antipater at the beginning of his reign to marry and beget children before departing for Persia. ${ }^{117}$ Elizabeth Baynham convincingly argues that this stance was governed by a wish to avoid being drawn into Macedonian factional feuds following marriage to a female member of one of the influential noble families, some of whom had opposed his succession. ${ }^{118}$ Moreover, in the first phase of the war against Darius III, Alexander's victories were not foreseeable and his position still insecure. His rule was curtailed by the control of influential Macedonian families, whose power he could not suffer to increase. ${ }^{119}$ Therefore, he could not afford to bring up a child who might have been preferred by the noble opposition as their ruler. ${ }^{120}$ When Alexander finally married he obviously still did not mean to give place to a potential rival. What seemed to have been at first glance a fatal lack of interest in a 'future without himself' 121 was probably part of his policy aimed at securing his rule. ${ }^{122}$

In Johann Hartlieb's reinvention of this history, however, Alexander remains a popular ruler without major threats to his authority. His idealised picture of Alexander left no room for Macedonian noble resentments or opposition to the rule of a heroic figure. Moreover, like in Gautier's Alexandreis, all references to homosexuality have been eliminated. Trude Ehlert comments that Hartlieb deliberately left out a marginal note hinting at some homosexual practices of Alexander. ${ }^{123}$ To sum up, the mother is the central female figure in Hartlieb's Alexanderroman. It echoes an image contained in a letter to Aristotle, where Alexander is cited as explicitly stating that he loves his mother, his sisters, and his tutor most of all. ${ }^{124}$ Hartlieb's translation of the Latin Alexander romance was as much a reinterpretation, which sought to provide an answer to why the famous Macedonian ruler failed to secure his heritage.

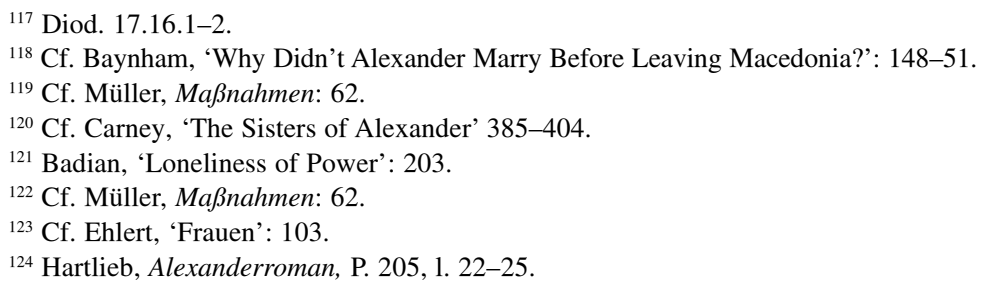




\section{Iskandarnameh by Nizami: Being Able to Fight and Feast}

Medieval Persian Alexander romances draw upon a number of sourcesthe $\delta$-recension of Pseudo-Callisthenes but also on Syrian accounts, the Qu'ran, Arabic legends and Persian material. ${ }^{125}$ This makes their reception of the Alexander legend more ambivalent. About 980-1010 Alexander was portrayed by the poet Firdawsi in the Shahnameh (Book of Kings) as a son of Darius III and legitimate heir to the Achaemenid throne. ${ }^{126}$ At the same time Firdawsi drew upon the negative tradition wherein Alexander was portrayed as an enemy of Iran who set fire to the royal palaces of Persepolis, destroyed the unity of empire, burnt the Zoroastrian scriptures and fostered enmity between Greece and Persia. ${ }^{127}$ This hostile tradition derives from Zoroastrian and Sassanid sources. In the sixth and seventh centuries Sassanid rulers sought to gain legitimacy by representing themselves as saviours of Iran, who re-established the order Alexander had destroyed. ${ }^{128}$ The Zoroastrians dismissed Alexander as an enemy of God Auramazdah, as well as an agent of lies, evil and darkness. ${ }^{129}$

Firdawsi found both traditions in his sources and combined the positive tradition of the heroic Alexander deriving from the translation of the Greek Alexander romance and the hostile tradition deriving from Sassanid propaganda. ${ }^{130}$ With regard to Alexander's relationship with women the Eastern view on Iskandar, the Persian name for Alexander, bears little resemblance to the original Greek version and its Western reconfigurations discussed earlier. Most of the Persian Alexander romances depict

${ }^{125}$ Cf. Cary, The Medieval Alexander: 38-61; Mangoun, The Gests of Alexander: 38-62; Ross, Medieval Illustrated Alexander Literature: 45-65; Sarkhosh Curtis, Mythen: 96; Southgate, 'Portrait of Alexander': 278.

${ }^{126}$ Cf. Mossé, Alexander der Große: 224; Sarkhosh Curtis, Mythen: 95-96; Southgate, 'Portrait of Alexander': 279; Yamanaka, 'Ambiguité': 341.

${ }^{127}$ Cf. Sarkhosh Curtis, Mythen: 96; Yamanaka, 'Ambiguité': 347. Alexander was blamed for the destruction of the empire although this happened after his death and was the result of the wars of the successors. Perhaps this argumentation was common also in Western Europe and yet another reason for Johann Hartlieb to apologise for Alexander's carelessness in regard to the problem of succession by blaming Roxane.

${ }^{128}$ Cf. Yamanaka, 'Ambiguité': 343, 349-52; Southgate, 'Portrait of Alexander': 279.

${ }^{129}$ Cf. Baynham, 'Alexander Romance': 4; Southgate, 'Portrait of Alexander': 278.

${ }^{130}$ Cf. Baynham, 'Alexander Romance': 5; Yamanaka, 'Ambiguité': 353. 
Alexander as a young and handsome polygamous character particularly attracted to beautiful and powerful women. He is portrayed as 'an ardent lover with numerous wives and concubines'. ${ }^{131}$ His 'extraordinary sexual energy is one of his heroic attributes'. ${ }^{132}$

In about 1191, the Persian poet Nizami wrote two metrical romances called Iskandarnameh (Book of Alexander), which celebrate Alexander as a warrior-king who then developed into a sage and finally a prophet. ${ }^{133}$ Nizami's narrative was influenced by the ninth-century Persian political philosophy of Farabi which laid down that the ideal king had to be a good politician and warrior, a philosopher and a prophet. ${ }^{134}$ Keeping to this view, Alexander's tutor Aristotle features as his wise vizier who taught him that victory could only be achieved through wisdom and learning. ${ }^{135}$ Alexander is depicted in a most favourable light as a just, merciful, glorious, ingenious, decisive and prudent ruler. ${ }^{136}$

The subject of Alexander's relationship with women plays a central role in Nizami's Iskandarnameh. Alexander's sensuality evidently does not exist in contradiction with his future role as a sage and prophet. ${ }^{137}$ As in medieval European reinterpretations of the Alexander legend, here too, Alexander marries Roxane, a daughter of king Darius III, in response to a plea of her dying father. ${ }^{138}$ In the Persian text he is supposed to have sent her to Greece soon after their wedding, while he continued waging wars. ${ }^{139}$ Unlike the image of a husband advocated by Christian morals, the Persian Alexander lives polygamously and has several love affairs during his military exploits, so that in the Iskandarnameh his mistresses enjoy a more prominent place than does his wife Roxane. ${ }^{140}$ For instance,

${ }^{131}$ Southgate, 'Portrait of Alexander': 278, 281.

132 Ibid.: 281.

${ }^{133}$ Cf. Sarkhosh Curtis, Mythen: 96, 99; Southgate, 'Portrait of Alexander': 279. The first metrical romance depicts Alexander as a king and warrior, the second as a sage and prophet.

${ }^{134} \mathrm{Cf}$. Bürgel, 'L'attitude d'Alexandre face à la philosophie grecque des trois poèmes epiques persans': 53-59.

${ }^{135} \mathrm{Cf}$. Southgate, 'Portrait of Alexander': 282.

${ }^{136}$ Nizami, Das Alexanderbuch. Iskandarname: I, 372.

${ }^{137}$ Cf. Southgate, 'Portrait of Alexander': 282.

${ }^{138}$ Iskandarnameh, I, 219.

${ }^{139} \mathrm{Ibid}$. I, 263. She is pregnant when she leaves Persia and gives birth to his son Alexandros.

${ }^{140}$ Interestingly, Nizami does not describe a love affair of Alexander and queen Nushabe, the Persian counterpart of Candacis with features of Thalestris. Nushabe is a chaste and 
he is described as falling in love with the daughter of the Indian king Porus whose kingdom he has conquered; Alexander marries her, spends some nights with her and moves on. ${ }^{141}$ On arriving in China the emperor there gifts him a beautiful Chinese female slave, reputed to be bold and brave, who at first does not appear to evoke the Macedonian ruler's interest and so is left behind, but they are destined to meet again. ${ }^{142}$ While fighting seven battles against the Russians, Alexander is aided by an unknown knight whose bravery and fighting skills are held to force a whole Russian army to retreat. Impressed by this accomplishment, Alexander recognises the Chinese slave girl as soon as the young 'knight' takes off his armoury. ${ }^{143}$ She tells him that she could not bear living without him and followed him secretly. ${ }^{144}$ His own judgement that a woman, even a brave woman, could never measure up to a man's bravery is proven wrong. ${ }^{145}$ Alexander immediately conceives a passion for her. ${ }^{146}$ After the decisive battle against the Russians he spends passionate nights with her, which Nizami describes in detail, comparing the couple to milk and sugar melting together. ${ }^{147} \mathrm{He}$ also invites his readers to enjoy their own life and the taste of wine just like Alexander did, pleasures not regarded sinful as in Christian morals, rather recommended as pleasant distractions following the arduous efforts of political life. ${ }^{148}$ Chastity is neither esteemed as a virtue nor viewed as a necessity for an ideal monarch. ${ }^{149}$

It is evident from these three different examples of the medieval Alexander romance that the legendary figure of Alexander was reinvented in terms drawn from the writer's cultural background, either into an ideal

beautiful warrior queen living with female soldiers. Alexander visits her and is enchanted by her grace and charms. They spend a night together feasting and drinking wine. When they meet again he is already in love with the Chinese slave girl and offers Nushabe in marriage to another man (Ibid. I, 297-308. 481-483).

${ }^{141}$ Ibid. I, 361-64.

${ }^{142}$ Ibid. I, 413-14.

${ }^{143}$ Ibid. I, 460-68.

${ }^{144}$ Ibid. I, 469-70.

145 Ibid. I, 415.

${ }^{146}$ Ibid. I, 471-73.

${ }^{147}$ Ibid. I, 486-98.

${ }^{148}$ Ibid. I, 483-86. Nizami comments that wine lets Alexander bloom like a rose (II, 262).

${ }^{149}$ Ibid. I, 498.

- The Medieval History Journal, 11, 2 (2008): 259-287 
Christian emperor ${ }^{150}$ or into an ideal oriental adventurer king. The cleric Gautier de Châtillon portrays him as chaste, innocent and self-restrained. In his eyes, a good Christian emperor has to control his sexual behaviour by casting it in the mould of Christian morals. Johann Hartlieb on the other hand pegs his construction of an ideal ruler onto Alexander's love for his mother, sister, and wife Roxane. Judging from a courtly perspective, Hartlieb was clearly aware of the importance of a positive dynastic image and of the propagandistic value of the representation of dynastic harmony in guaranteeing legitimacy. The end of his Alexanderroman problematises the issue of succession: Alexander's empire collapses after his death because he did not manage to ensure a secure and legitimate succession. This is the lesson Hartlieb's final chapters teach and he was certainly drawing upon his own experience at the German courts while being in diplomatic mission. To establish and consolidate dynastic rule princes are obliged to ensure legitimate heirs. As a result, his wife plays an important role at the end of the Alexanderroman. Nizami's Alexander figure resembles the powerful oriental monarchs whose sexual prowess is one of their signs of power and strength: the independent qualities of the women crossing his path emphasise his heroic qualities. Only in the Eastern medieval romance was it possible for Alexander to be at the same time a philosopher-king, sage and a polygamous and romantic lover.

As the different conceptions of the Alexander figure illustrate, Gautier's inner world is a clerical Christian one, Hartlieb thinks in dynastic terms emphasising the importance of legitimacy and succession, and Nizami is influenced by Persian political philosophy as well as by poetic tradition. In all three cases, women serve as a medium through which the moral standards or royal virtues of Alexander could be fixed. The figures of women play no individual or autonomous roles in the medieval Alexander romances but were portrayed stereotypically, as sources to throw light on Alexander's virtues or vices. ${ }^{151}$ The medieval texts reveal more about their writers, their literary concepts and their political, intellectual, social and cultural moorings, which underpin their re-workings

${ }^{150}$ However, negative Christian medieval traditions could also characterise him as a lecherous sinner.

${ }^{151}$ For example, in Gautier's Alexandreis the ekphrasis of Darius' dead young wife Stateira's tomb (IV, 176-274) whose chastity was respected by Alexander despite her beauty only serves to allude to some of his self-reflections. Cf. Tilliette, 'Gautier': 282-83.

The Medieval History Journal, 11, 2 (2008): 259-287 
of ancient Greek historical materials to recreate the legendary figure of Alexander that circulated among medieval elites.

\section{References}

\section{Primary Sources}

Hartlieb, Johann. 1980. Alexanderroman. Edition des Cgm 581, edited and translated by Rudolf Lechner-Petri, Hildesheim.

von Châtillon, Walter. 1990. Das Lied von Alexander dem Großen, edited and translated by Gerhard Streckenbach, Heidelberg.

von Etzenbach, Ulrich, Alexander, edited and translated by Wendelin Toischer, Tübingen, 1888 (reprint Hildesheim/New York 1974).

Nizami. 1991. Das Alexanderbuch. Iskandarname, edited and translated by Christoph Bürgel, Zurich.

\section{Secondary Sources}

Badian, Ernst. 1960. 'The Death of Parmenio', Transactions and Proceedings of the American Philological Association, vol. 91: 324-33.

1964. 'Alexander the Great and the Loneliness of Power', in his Studies in Greek and Roman History, Oxford.

Baynham, Elizabeth J. 1995. "Who Put the "Romance" in the Alexander Romance? The Alexander Romances within Alexander Historiography', The Ancient History Bulletin, vol. 9: 1-13.

- 1998a. Alexander the Great. The Unique History of Quintus Curtius, Ann Arbor. 1998b. 'Why Didn't Alexander Marry Before Leaving Macedonia? Observations on Factional Politics at Alexander's Court in 336-334 в.c.', Rheinisches Museum, vol. 141: 148-51.

. 2001. 'Alexander and the Amazons', Classical Quarterly, vol. 51: 115-26.

. 2003. 'The Ancient Evidence for Alexander the Great', in Joseph Roisman (ed.), Brill's Companion to Alexander the Great, Leiden/Boston: 3-29.

Bosworth, Albert Brian.1981. 'A Missing Year in the History of Alexander the Great', Journal of Hellenic Studies, vol. 101: 17-39. . 2003. 'The Sources', in Ian Worthington (ed.), Alexander the Great. A Reader, London/New York.

Brocker, Max. 1966. Aristoteles als Alexanders Lehrer in der Legende, Bonn.

Bürgel, J. Christoph. 1999. 'L'attitude d'Alexandre face à la philosophie grecque des trois poèmes epiques persans', in Laurence Harf-Lancner et al. (ed.), Alexandre le Grand dans les literatures occidentals et proche-orientals, Paris: 53-59.

Cary, George. 1954. 'Alexander the Great in Mediaeval Theology', Journal of the Warburg and Courtauld Institutes, vol. 17: 98-114.

. 1956. The Medieval Alexander, Cambridge.

- The Medieval History Journal, 11, 2 (2008): 259-287 
Carney, Elizabeth D. 1975. Alexander the Great and the Macedonian Aristocracy, Durham. . 1988. 'The Sisters of Alexander: Royal Relicts?', Historia, vol. 37: 385-404.

. 2003. 'Women in Alexander's Court', in Joseph Roisman (ed.), Brill's Companion to Alexander the Great, Leiden/Boston: 227-52.

2006. Olympias, Mother of Alexander the Great, London/New York.

Destombes, Marcel. 1965. 'The Mappamundi of the Poem Alexandreidos by Gautier de Châtillon', Imago Mundi, vol. 19: 10-12.

Ehlert, Trude. 1989. 'Alexander und die Frauen in spätantiken und mittelalterlichen Alexander-Erzählungen', in Willi Erzgräber (ed.), Kontinuität und Transformation, Sigmaringen: $81-103$.

Franke, Birgit. 2000. 'Herrscher über Himmel und Erde. Alexander der Große und die Herzöge von Burgund', Marburger Jahrbuch für Kunstwissenschaft, vol. 27: 121-69.

Glock, Andreas. 2000. 'Alexander Gallicus? Die Alexandreis Walters von Châtillon als Fall implizierter antik-mittelalterlicher Dependenz und Selbstkonstituierung', in Jan Cölln, Susanne Friede and Hartmut Wulfram (eds), Alexanderlegenden im Mittelalter, Göttingen: 280-97.

Göller, Karl Heinz. 1989. 'Alexander und Dindimus: West-östlicher Disput über Mensch und Welt', in Willi Erzgräber (ed.), Kontinuität und Transformation der Antike im Mittelalter, Sigmaringen: 105-19.

Hampl, Franz. 1965. Alexander der Große, Göttingen, Berlin, Frankfurt (second edition).

Hammond, Nicholas G.L. 1980. Alexander the Great. King, Commander, and Statesman, London.

- 1989. The Macedonian State. The Origins, Institutions, and History, Oxford.

Harich, Henriette. 1987. Alexander Epicus. Studien zur Alexandreis Walters von Châtillon, Graz.

Heckel, Waldemar. 1992. The Marshals of Alexander's Empire, London/New York.

Hertz, Wilhelm. 1905. 'Die Sage vom Giftmädchen', in Wilhelm Hertz (ed.), Gesammelte Abhandlungen, Stuttgart/Berlin.

Hofmann, Inge. 1978. Beiträge zur meroitischen Chronologie, St. Augustin.

Holt, Frank L. 1999. 'Alexander the Great Today: In the Interests of Historical Accuracy?', The Ancient History Bulletin, vol. 13: 111-17.

Jasnow, Richard. 1997. 'The Greek Alexander Romance and Demotic Egyptian Literature', Journal of Near Eastern Studies, vol. 56: 95-103.

Jouanno, Corinne. 2002. Naissance et métamorphose du roman d'Alexandre, Paris.

Klein, Richard. 2006. 'Zur Verwendung der Alexandertopik in der spätantiken Panegyrik', in Vasile Lica (ed.), Philia. Festschrift für Gerhard Wirth zum 80. Geburtstag, Galati: 175-202.

Koulakiotis, Elias. 2006. Genese und Metamorphosen des Alexandermythos im Spiegel der griechischen nicht-historiographischen Überlieferung bis zum 3. Jahrhundert $n$. Chr. Konstanz.

Kratz, Dennis. 1980. Mocking Epic. Waltharius, Alexandreis and the Problem of Christian Heroism, Madrid.

Lechner-Petri, Rudolf. 1980a. 'Johann Hartliebs Leben und Werke', in Johann Hartlieb, Alexanderroman. Edition des Cgm 581, edited and translated by Rudolf Lechner-Petri, Hildesheim: 3-9.

The Medieval History Journal, 11, 2 (2008): 259-287 
Lechner-Petri, Rudolf. 1980b. 'Quellen und Übersetzungstechnik Johann Hartliebs', in Johann Hartlieb, Alexanderroman. Edition des Cgm 581, edited and translated by Rudolf Lechner-Petri, Hildesheim: 10-16.

Loomis, Roger S. 1918. 'Alexander the Great's Celestial Journey', The Burlington Magazine for Connoisseurs, vol. 32: 136-40, 177-85.

Mangoun, F.P. 1929. The Gests of Alexander of Macedon, Cambridge/Massachusetts.

Merkelbach, Reinhold. 1977. Die Quellen des griechischen Alexanderromans, München (second edition).

Mossé, Claude. 2004. Alexander der Große. Leben und Legende, Düsseldorf/Zürich.

Müller, Sabine. 2003. Maßnahmen der Herrschaftssicherung gegenüber der makedonischen Opposition bei Alexander dem Großen, Frankfurt.

- 2006. 'Alexander der Große als neuer Achilles. Die panhellenische und makedonische Repräsentation des Persienkrieges in den Medien der königlichen Propaganda', in Stefan Jaeger and Christer Petersen (eds), Zeichen des Krieges in Literatur, Film und den Medien. II: Ideologisierungen und Entideologisierungen, Kiel: 263-94.

—. 2007. 'Luxus, Sittenverfall, Verweichlichung und Kriegsuntüchtigkeit: Die Codes der Dekadenz in den antiken Quellen', in Christian Hoffstadt (ed.), Dekadenzen, Bochum/Freiburg: 13-52.

Noll, Thomas. 2005. Alexander der Große in der nachantiken bildenden Kunst, Mainz.

Penzer, Norman M. 1952. Poison-Damsels and other Essays in Folklore and Anthropology, London.

Peter Orth, 'Magnus in exemplo est. Alexander der Große in lateinischen ExemplaSammlungen des Mittelalters' (http://www.mgh.de/ Poetae/Mitarbeiter/Skript $\% 20$ Alexander\%20Magnus.pdf)

Pfrommer, Michael. 2002. Alexander der Große. Auf den Spuren eines Mythos, Mainz.

Robinson, Charles A. Jr. 1949. Alexander the Great. The Meeting of East and West in World Government and Brotherhood, New York.

Ross, David J.A. 1963. A Guide to Medieval Illustrated Alexander Literature, London.

Ryan, W.F. and Charles B. Schmitt. 1982. Pseudo-Aristotle: The Secret of Secrets: Sources and Influences, London.

Sarkhosh Curtis, Vesta, 1994. Persische Mythen, Stuttgart.

Schachermeyr, Fritz. 1973. Alexander der Große. Das Problem seiner Persönlichkeit und seines Wirkens, Wien.

Schmidt, Victor M. 1995. A Legend and its Image. The Aerial Flight of Alexander the Great in Medieval Art, Groningen.

Schnell, Rüdiger. 1989. 'Der Heide Alexander im christlichen Mittelalter' in Willi Erzgräber (ed.), Kontinuität und Transformation der Antike im Mittelalter, Sigmaringen: 45-63.

Schlechtweg-Jahn, Ralf. 2002. 'Hybride Machtgrenzen in deutschsprachigen Alexanderromanen', in Ulrich Mölk (ed.), Herrschaft, Ideologie, Geschichtskonzeption. Alexanderdichtungen im Mittelalter, Göttingen: 267-89.

Southgate, Minoo S. 1977. 'Portrait of Alexander in Persian Alexander-Romances of the Islamic Era', Journal of the American Oriental Society, vol. 97: 278-84.

Stoneman, Richard. 1991. The Greek Alexander Romance, London.

- The Medieval History Journal, 11, 2 (2008): 259-287 
Stoneman, Richard. 1999a. 'The Medieval Alexander', in Heinz Hoffmann (ed.), Latin Fiction, London/New York: 238-52.

. 1999b. 'The Latin Alexander', in Heinz Hoffmann (ed.), Latin Fiction, London/ New York: $167-86$.

. 2003. 'The Legacy of Alexander in Ancient Philosophy', in Joseph Roisman (ed.), Brill's Companion to Alexander the Great, Leiden/Boston: 338-43.

Tarn, William W. 1948. Alexander the Great, London.

Tilliette, Jean-Yves. 1999. 'L'Alexandréide de Gautier de Châtillon: Enéide médiévale ou 'Virgile travesty?', in Laurence Harf-Lancner Claire Kappler and Francoise Suard (eds), Alexandre le Grand dans les literatures occidentals et proche-orientals, Paris: 275-87.

van Bekkum, W. Jac. 1986. 'Alexander the Great in Medieval Hebrew Literature', Journal of the Warburg and Courtauld Institutes, vol. 49: 218-26.

von Châtillon, Walter. 1990. Das Lied von Alexander dem Großen, edited and translated by Gerhard Streckenbach, Heidelberg.

Wiener, Claudia. 2001. Proles vaesana Philippi totius malleus orbis: Die Alexandreis Walters von Châtillon und ihre Neudeutung von Lucans Pharsalia im Sinne des typologischen Geschichtsverständnisses, München/Leipzig.

Wilcken, Ulrich, 1931. Alexander der Große, Leipzig.

Wirth, Gerhard. 1993. Der Brand von Persepolis. Folgerungen zur Geschichte Alexanders des Großen, Amsterdam.

2005. 'Pseudo-Kallisthenes', in Hatto H. Schmitt and Ernst Vogt (eds), Lexikon des Hellenismus, Wiesbaden (third edition): 513.

Wiesehöfer, Josef. 2005. Das antike Persien von 550 v. Chr. bis 650 n. Chr., Düsseldorf (third edition).

Wisbey, Roy. 1966. Das Alexanderbild Rudolfs von Ems, Berlin.

Wulfram, Hartmut. 2002. 'Der Übergang vom persischen zum makedonischen Weltreich bei Curtius Rufus und Walter von Châtillon' in Ulrich Mölk (ed.), Herrschaft, Ideologie, Geschichtskonzeption. Alexanderdichtungen im Mittelalter, Göttingen: 40-76.

Yamanaka, Yuriko. 1999. 'Ambiguité de l'image d'Alexandre chez Firdawsi: Les traces des traditions sassanides dans le Livre des Rois', in Laurence Harf-Lancner Claire Kappler and Francoise Suard (eds), Alexandre le Grand dans les literatures occidentals et proche-orientals, Paris: 341-53.

The Medieval History Journal, 11, 2 (2008): 259-287 